\title{
Getting more than a fair share: nutrition of worker larvae related to social parasitism in the Cape honey bee Apis mellifera capensis
}

\author{
Johan N.M. CALis ${ }^{\mathrm{a} *}$, Willem J. Boot ${ }^{\mathrm{a}}$, Mike H. Allsopp ${ }^{\mathrm{b}}$, \\ Madeleine BEEKMAN ${ }^{\mathrm{c}}$
}

\footnotetext{
a Laboratory of Entomology, Wageningen University, PO Box 8031, 6700 EH Wageningen, The Netherlands

${ }^{\mathrm{b}}$ Honeybee Research Section, ARC-Plant Protection Research Institute, Private Bag X5017, Stellenbosch, 7599, South Africa

c Schools of Biological Sciences \& Mathematics and Statistics, University of Sydney, A12, Sydney, NSW 2006, Australia
}

(Received 19 July 2001; revised 2 October 2001; accepted 21 November 2001)

\begin{abstract}
Besides activation of ovaries and thelytokous reproduction of Cape workers, larval nutrition is an important aspect in parasitism of the African honey bee. When reared by workers of other subspecies, Cape larvae receive more food which is slightly more royal jelly-like. This results in worker-queen intermediates, with reduced pollen combs, enlarged spermathecae and higher numbers of ovarioles. The intermediates weigh more and develop faster than normal workers. The appearance of worker-queen intermediates probably affects parasitism of the African honey bee colonies by Cape workers. Different levels of larval nutrition resulting in less distinct caste differentiation may be important for the reproductive success of Cape workers in their own colonies. Similar processes, albeit less pronounced, may occur in colonies of other subspecies.
\end{abstract}

Apis mellifera capensis / A. m. scutellata / Cape honey bee / African honey bee / parasitism / larval feeding / caste determination

\section{INTRODUCTION}

In 1990 the Cape honey bee, Apis mellifera capensis Escholtz, was moved out of its native range by beekeepers and introduced into the former Transvaal province (now the Northern Province) (Martin et al., 2002; Neumann and Hepburn, 2002). These Cape honey bee colonies were housed in apiaries containing colonies of the African honey bee, Apis mellifera scutellata Lepeletier, which resulted in the

\footnotetext{
* Correspondence and reprints

E-mail: johan.calis@users.ento.wau.nl
} 
invasion of the African honey bee colonies by Cape honey bee workers. These Cape workers were able to activate their ovaries and become reproductively active (Neumann and Hepburn, 2002). Unlike other honey bee subspecies, where workers produce males by arrhenotokous parthenogenesis, workers of the Cape honey bee produce female offspring through thelytoky (Onions, 1912, 1914; Anderson, 1963; Hepburn and Radloff, 2002). As a result, the number of Cape workers in the colonies increase, eventually resulting in the death of the African queen. In addition, Cape workers are not involved in foraging, which may lead to the death of the colony. Alternatively, a Cape queen is produced from the worker-laid eggs, and subsequently normal workers are produced from queen-laid eggs (Allsopp and Crewe, 1993).

Originally, the Cape honey bee only occurred in fynbos region of the Eastern and Western Cape Provinces of South-Africa (Hepburn and Jacot Guillarmod, 1991) and the African honey bee in the rest of South Africa, with a hybrid zone in between (Hepburn et al., 1998). This hybrid zone has apparently been stable for decades with neither subspecies increasing its range (Hepburn and Crewe, 1991; Hepburn and Jacot Guillarmod, 1991). Although colonies of the Cape honey bee had previously been moved into African honey bee area (in 1927: Lundie, 1954 and 1977: Johannesmeier, 1983) the Cape honey bees were eradicated within a few years. The most recent introduction, however, has led to devastating results with vast numbers of African bee colonies being killed by invading workers of the Cape honey bee (Allsopp and Crewe, 1993).

Activation of ovaries and subsequent thelytokous reproduction are prerequisites for usurping African honey bee colonies by Cape workers, which can be regarded as social parasitism. Normally, social parasites are a different (although sometimes closely related) species than their host. Social parasites have lost their worker caste and the brood (reproductive females and males) are reared by the workers of the host. Development of parasitic brood in the host colony can occur in two ways. Parasitic larvae can have a lower caste threshold than the host species, which means that they can develop into sexual females with less food than the sexual females of the host (Nonacs and Tobin, 1992). This has been shown to occur in ants where the reproductive females of the parasite are the same size as the workers of the host (Aron et al., 1999). The second way is to get more food than host worker larvae (Nonacs and Tobin, 1992). The latter occurs when Cape honey bee brood is reared by nurse bees of other honey bee races, which leads to more queen-like individuals (Beekman et al., 2000). Hence, larval nutrition is an important aspect of social parasitism by Cape honey bees.

\section{CASTE DETERMINATION IN HONEY BEES}

Caste in honey bees is normally determined by the selective feeding of female larvae whereby larvae destined to become queens receive more food which also has a different composition (Beetsma, 1979). Differential feeding leads to very distinct worker and queen castes. The critical difference between food fed to worker- and queen-larvae seems to be the concentration of hexose sugars; royal jelly and worker jelly contain about 34 and 12 percent sugar respectively (Shuel and Dixon, 1959).

Through manipulation, intermediates between the worker and queen castes can be obtained. When glucose and fructose is experimentally added to food fed to larvae, these larvae will turn into workers with queen-like characters (Asencot and Lensky, 1976). Treating female larvae with juvenile hormone also leads to the production of worker-queen intermediates (Wirtz 
and Beetsma, 1972). Applying juvenile hormone does not induce isolated morphological features, but affects the complex of caste characters as a whole (Wirtz and Beetsma, 1972). Functional worker characteristics (pollen combs and pollen baskets on the hind legs) decrease and at the same time functional queen characteristics (short developmental time, weight, a large spermatheca and a large number of ovarioles) increase. The same was found when queens were artificially reared from worker larvae grafted at different developmental stages (Dedej et al., 1998).

\section{WORKER-QUEEN INTERMEDIATES IN THE CAPE HONEY BEE}

Although it is generally assumed that brood in social Hymenoptera has no influence over caste determination (with the exception of social parasites (Nonacs and Tobin, 1992) and some stingless bees
(Ratnieks, 2001)), it has recently been shown that workers of the Cape honey bee have considerable influence (Beekman et al., 2000). When reared in a colony of a different subspecies, larvae of the Cape honey bee receive more food that is also slightly more royal jelly-like. The resulting bees have characteristics intermediate between workers and queens. In general, such worker-queen intermediates have enlarged spermathecae and higher numbers of ovarioles compared to workers (Fig. 1). They are also heavier than workers, develop faster and have reduced pollen combs (Tab. I; Beekman et al., 2000). This phenomenon, the increased feeding resulting in heavier bees with larger spermathecae and more ovarioles, has also been reported for queenless Cape honey bee colonies (Woyke, 1979).

The study of Beekman et al. (2000) was done using European honey bees as host for the Cape honey bee larvae. We recently found the same phenomenon when the African honey bee is used as a host. Cape

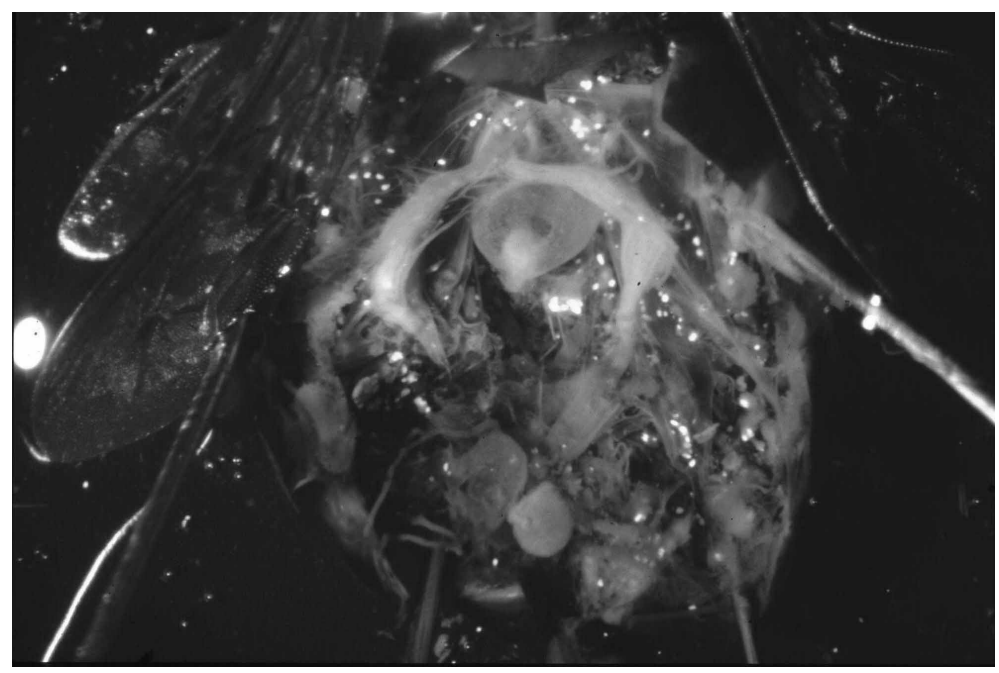

Figure 1. Callow Cape worker reared by European workers (specimen used in Beekman et al., 2000). Photograph of dorsal view of the inside of the abdomen after the gut has been taken out. The bundels of ovarioles are visible situated above the crop and the spermatheca is visible in the caudal part of the abdomen. 
Table I. Characteristics of emerging bees in relation to the colony where the larvae were reared. Experiment in Stellenbosch (unpublished data from authors, see Fig. 2) and experiment in Wageningen (data from Beekman et al., 2000).

\begin{tabular}{|c|c|c|c|c|}
\hline & \multicolumn{2}{|c|}{$\begin{array}{c}\text { Experiment Stellenbosch } \\
\text { South-Africa }\end{array}$} & \multicolumn{2}{|c|}{$\begin{array}{l}\text { Experiment Wageningen } \\
\text { The Netherlands }\end{array}$} \\
\hline & $\begin{array}{l}\text { Cape larvae } \\
\text { reared in } \\
\text { Cape colony } \\
(\mathrm{n}=15)\end{array}$ & $\begin{array}{c}\text { Cape larvae } \\
\text { reared in } \\
\text { African colony } \\
\quad(n=15)\end{array}$ & $\begin{array}{l}\text { Cape larvae } \\
\text { reared in } \\
\text { Cape colony } \\
(\mathrm{n}=23)\end{array}$ & $\begin{array}{c}\text { Cape larvae } \\
\text { reared in } \\
\text { European colony } \\
(\mathrm{n}=16)\end{array}$ \\
\hline $\begin{array}{l}\text { Average } \\
\text { (Std) }\end{array}$ & $\begin{array}{l}0.076 \\
(0.009)\end{array}$ & $\begin{array}{c}0.085 \\
(0.008)\end{array}$ & $\begin{array}{c}0.111 \\
(0.006)\end{array}$ & $\begin{array}{c}0.124 \\
(0.003)\end{array}$ \\
\hline Postcapping period (h) & $\begin{array}{l}274.87 \\
(6.43)\end{array}$ & $\begin{array}{l}257.03 \\
(10.71)\end{array}$ & $\begin{array}{l}260.27 \\
(9.83)\end{array}$ & $\begin{array}{l}252.82 \\
(4.87)\end{array}$ \\
\hline Ovarioles & $\begin{array}{l}33.8 \\
(8.8)\end{array}$ & $\begin{array}{c}42.5 \\
(14.2)\end{array}$ & $\begin{array}{l}13.6 \\
(2.5)\end{array}$ & $\begin{array}{l}25.4 \\
(5.0)\end{array}$ \\
\hline Spermatheca $(\mathrm{mm})$ & $\begin{array}{c}0.24 \\
(0.16)\end{array}$ & $\begin{array}{c}0.68 \\
(0.07)\end{array}$ & $\begin{array}{c}0.50 \\
(0.11)\end{array}$ & $\begin{array}{c}0.78 \\
(0.05)\end{array}$ \\
\hline Hairs & $\begin{array}{c}4.1 \\
(1.5)\end{array}$ & $\begin{array}{l}16.8 \\
(6.1)\end{array}$ & $\begin{array}{c}9.7 \\
(5.3)\end{array}$ & $\begin{array}{c}47.3 \\
(15.0)\end{array}$ \\
\hline
\end{tabular}

worker-laid brood from parasitized African honey bee colonies in Pretoria, were raised in both African honey bee colonies and Cape honey bee colonies in Stellenbosch. Brood in the African honey bee colonies developed into worker-queen intermediates, whereas brood in the Cape honey bee colonies developed into normal Cape honey bee workers (Fig. 2; Tab. I).

\section{NUTRITION OF WORKER LARVAE RELATED TO SOCIAL PARASITISM IN THE CAPE HONEY BEE}

As Cape worker larvae receive more food when raised in African honey bee colonies, this is bound to affect the process of

Figure 2. Effects of rearing of Cape larvae from Pretoria by African or Cape workers. Emerging Cape bees reared by African workers compared to those reared by Cape workers show a decrease of the postcapping period. An increase was shown for the weight at emergence, the number of ovarioles, the size of the spermatheca and the number of hairs between the two lowest pollen combs on the basitarsus. Differences were tested with Kruskal and Wallis test. All differences were significant $(P<0.05)$ except for the number of ovarioles $(P=0.077)$. Frames with brood from a parasitized African honey bee colony were flown to Stellenbosch. Round pieces of comb with a diameter of approximately $5 \mathrm{~cm}$ were cut from these combs and one piece was inserted into a brood comb of two African honey bee colonies (originating from Keimoes, Orange River) and two Cape honey bee colonies. We considered cells that were capped between four and five days after insertion and recorded cell capping every five hours. Nine days after capping, combs were placed in an incubator $\left(35^{\circ} \mathrm{C}\right)$. Emergence of each specific cell was recorded every four hours, whereas the bees were prevented to walk freely by a gauze screen covering the cell entrances. Fresh weight was measured upon emergence, after which the bees were stored individually in a freezer until further measurements were made. 


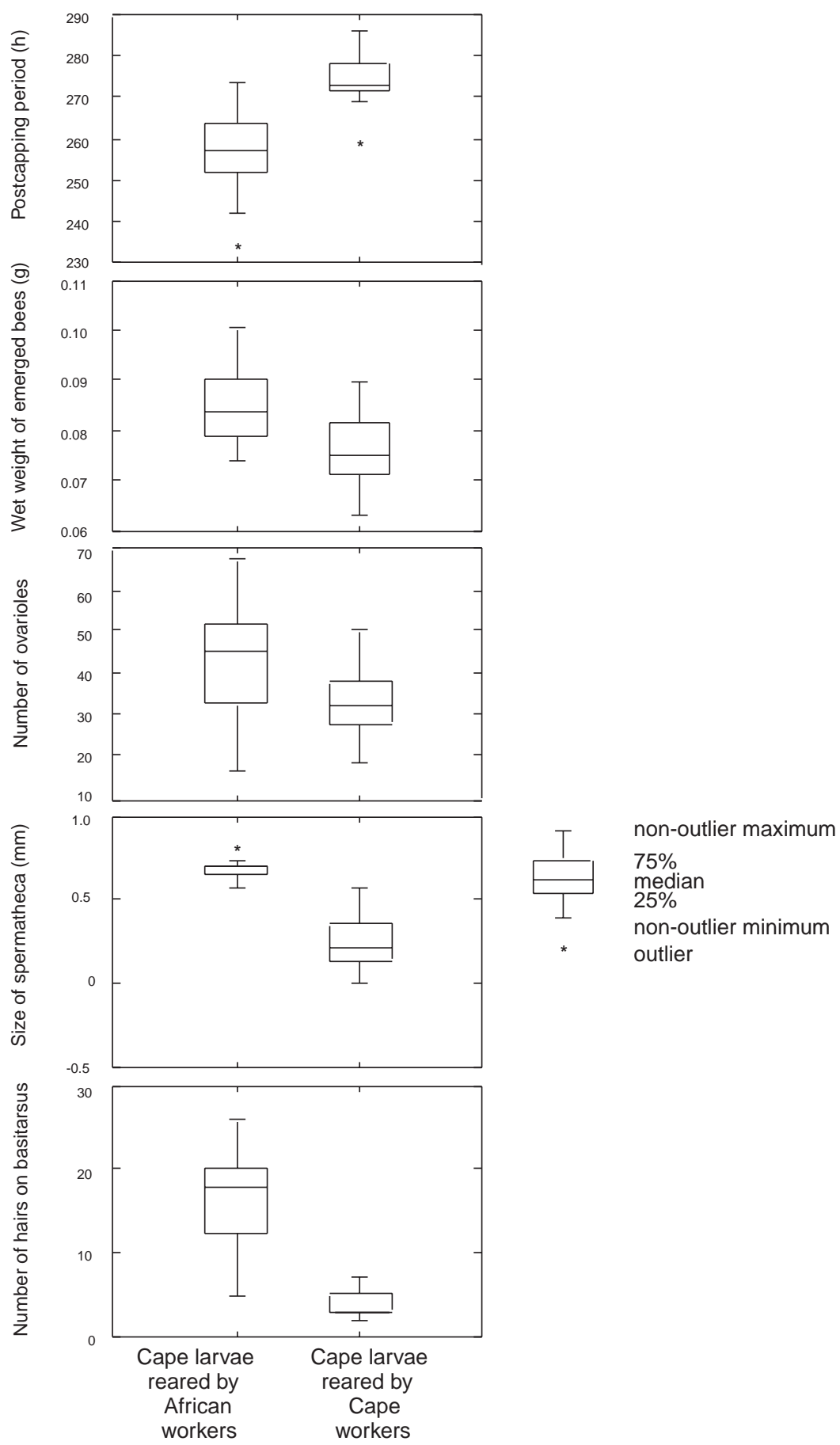


social parasitism. The resulting workerqueen intermediates can be expected to be better reproducers compared with normal Cape workers, and to be treated in a more queen-like fashion by other workers. Indeed, these worker-queen intermediates may be unable to perform normal worker tasks. Like others we have observed the striking difference in colour between foragers and bees inside the colony (but see Radloff et al., 2002). Dark-pigmented Cape bees stay inside the colony and apparently produce large numbers of eggs, whereas the yellow African workers are the only ones foraging.

It is well known that the mandibular gland secretions and the structure and number of tergal glands are more queen-like in Cape workers compared with workers of the African honey bee (Crewe and Velthuis, 1980; Allsopp, 1988; Hepburn and Allsopp, 1994; Wossler and Crewe, 1999; Wossler et al., 2000; Wossler, 2002). When in a queenright Cape honey bee colony, these Cape workers behave as normal honey bee workers, but under queenless conditions or when in a non-Cape honey bee colony (or caged with non-Cape honey bees) they change their pheromonal bouquets and produce vast quantities of queenlike pheromones (Crewe and Velthuis, 1980; Velthuis et al., 1990; Hepburn and Allsopp, 1994; Simon et al., 2001). When Cape larvae are reared into worker-queen intermediates, the pheromonal bouquet of the resulting intermediates is likely to be even more queen-like, which will further enhance parasitism.

Normally, worker ovary activation is very rare in queenright honey bee colonies (Ratnieks, 1993). This also holds for Cape honey bees (Hepburn, 1992; Hepburn et al., 1991; Reece, 2002). Even when workers do lay eggs, and approximately $0.01 \%$ of the workers have activated ovaries in non-Cape honey bees (Ratnieks and Visscher, 1989), these eggs are rapidly removed by other workers, defined as worker-policing
(Ratnieks and Visscher, 1989). However, eggs laid by Cape bees that have invaded colonies of the African honey bee escape policing (Wossler et al., 2001; Martin et al., 2002 , in press) and develop into adult bees. Honey bee queens mark their eggs and the source of this egg-marking pheromone is hypothesised to be the Dufour's gland (Ratnieks, 1995). If eggs produced by Cape workers are also marked with queen-like pheromones, this could result in non-Cape workers perceiving these eggs as being queen-laid. Hence, the absence of worker policing of Cape worker eggs. The eggmarking pheromone of worker-queen intermediates may even be more queen-like.

\section{WHY DO WORKER-QUEEN INTERMEDIATES APPEAR IN THE CAPE HONEY BEE?}

As worker and queen tasks differ completely, well distinct worker and queen castes are expected that both perform well in their own tasks. Fitness of both is increased by enhancing performance of the whole colony, which in some ways is the unit natural selection is acting upon. In fact, this is found in normal queenright colonies of all A. mellifera subspecies, including the Cape honey bee (Moritz and Southwick, 1992).

So why do we find worker-queen intermediates when Cape worker bees are raised in colonies of other A. mellifera subspecies? Apparently, communication between Cape worker larvae and nurse bees of other subspecies is disturbed, leading to increased feeding. Regardless of whether this is adaptive or not, it has a considerable effect on fitness of bees if caste determination is less distinct, because the colony will either perform worse than normal or because some of the workers will increase their fitness directly by social parasitism.

In normal queenright colonies female larvae are selected to get just enough food 
to make them optimal workers. In queenless colonies this may be different. Using European honey bees, Woyke (1999) showed that after colonies become queenless the worker larvae get more food than before. This increased nutrition may result in more queen-like workers. Actually, Kuwabara (1947) showed that workers reared under queenless conditions have increased numbers of ovarioles. This interesting effect may be functional. Upon queenlessness, there is a fair chance of becoming hopelessly queenless, after which the remaining workers can only rear drones until the death of the colony. If we assume that well-fed workers are eventually better egg-layers, obtaining more food may increase fitness of the bees.

In Cape honey bees, Moritz et al. (1996) showed that a few patrilines dominate when workers start reproducing (thelytokously) after colonies have become queenless. In the light of our recent findings, it is tempting to speculate that larvae of these patrilines receive more food than others. In a queenless colony they will be slightly more queen-like and thus may have a better chance of becoming a laying worker. Indeed, Woyke (1979) already demonstrated that in queenless Cape honey bee colonies increased larval feeding results in production of worker-queen intermediates. In Cape honey bees, colonies with laying workers often survive and eventually rear a new queen (Allsopp and Hepburn, 1997), which implies that becoming a laying worker may greatly increase the fitness of an individual bee. Hence, the above examples imply that bees may be selected to get more food as a larva, especially if colonies often lose their queen.

The critical difference between Cape honey bees and other honey bees is that worker reproduction occurs under queenright conditions, provided the queen present is not a Cape queen. If Cape honey bees meet honey bees of the neighbouring subspecies $A$. m. scutellata, their possibili- ties to directly increase fitness enlarges (Moritz, 2002). In the former Transvaal, a region with African honey bees all around, introduction of Cape honey bees has led to social parasitism of the African honey bee colonies. This can be regarded as an extreme. The same processes may happen in the natural zone were African and Cape honey bees are hybridised. If so, disturbed communication between workers and larvae with respect to the amount of food to be provided happens regularly. Thus, larval nutrition in relation to subsequent worker reproduction may play an important role in the hybrid zone.

\section{CONCLUSION}

In this review we have argued that activation of ovaries and subsequent thelytokous reproduction play in concert with less distinct caste differentiation due to different levels of larval nutrition. Focusing on nutrition of worker larvae has given us a more comprehensive view on the process of social parasitism by the Cape honey bee.

\section{ACKNOWLEDGEMENTS}

J.C. and W.B. visited SA in November 2000 on a travel grant of the Netherlands Organisation for Scientific Research (NWO) and financial support by MITOX. They are supported by Netherlands Foundation for the Advancement of Tropical Research (WOTRO). M.B. is supported by the Australian Research Council. Theresa Wossler is thanked for her help in obtaining Cape worker-laid brood from Pretoria and Louis van Niekerk is thanked for obtaining African honey bee colonies.

\footnotetext{
Résumé - Obtenir plus qu'une juste part : relation entre la nutrition des larves d'ouvrières et le parasitisme social chez l'abeille du Cap, Apis mellifera capensis. Le déplacement de l'abeille du Cap, Apis mellifera capensis Escholtz, hors
} 
de son aire d'origine dans la Province du Nord de la République sudafricaine a entraîné un parasitisme de l'abeille africaine, Apis mellifera scutellata Lepeletier. Les ouvrières du Cap envahissent les colonies d'abeilles africaines et prennent possession de la reproduction. Il en résulte que les colonies dépérissent et éventuellement meurent. Nous défendons ici l'idée que, outre l'activation des ovaires et la reproduction thélytoque des ouvrières du Cap, la nutrition larvaire représente un aspect important dans le parasitisme de l'abeille africaine. Lorsqu'elles sont élevées par des ouvrières d'autres sous-espèces, les larves de l'abeille du Cap reçoivent une nourriture en plus grande quantité et de qualité légèrement plus proche de la gelée royale. Cela aboutit à des individus intermédiaires entre la reine et l'ouvrière qui possèdent des peignes à pollen réduits, une spermathèque plus développée et un plus grand nombre d'ovarioles. Ces individus intermédiaires ont un poids plus élevé et un développement plus rapide que les ouvrières normales (Fig. 1, Tab. I). Nous apportons des données nouvelles sur le développement du couvain pondu par les ouvrières du Cap dans des colonies d'abeilles africaines parasitées de la région de Prétoria, couvain qui fut élevé à la fois dans des colonies d'abeilles africaines et dans des colonies d'abeilles du Cap à Stellenbosch. Le couvain dans les colonies d'abeilles africaines a donné des individus intermédiaires entre la reine et l'ouvrière, tandis que le couvain élevé dans les colonies d'abeilles du Cap s'est développé en ouvrières du Cap normales (Fig. 2, Tab. I). On peut s'attendre à ce que les intermédiaires reine-ouvrière soient de meilleures reproductrices que les ouvrières du Cap normales et qu'elles soient plus traitées comme des reines. Ceci agit vraisemblablement sur le parasitisme des colonies d'abeilles africaines par les abeilles du Cap dans la Province du Nord de la République sudafricaine. En outre une différence de niveaux dans le nourrissement larvaire, aboutissant à une différenciation des castes moins nette, peut être importante pour le succès reproducteur des ouvrières, particulièrement en cas de colonies orphelines. La zone d'hybridation entre l'abeille du Cap et l'abeille africaine est d'un intérêt particulier car on peut s'attendre à trouver une grande variation parmi les ouvrières d'une colonie.

\section{Apis mellifera capensis / Apis mellifera scutellata / parasitisme / nourrissement larvaire / détermination des castes}

\section{Zusammenfassung - Mehr als den ge- rechten Teil bekommen: Zusammenhang der Ernährung von Arbeiterinnenlarven und Sozialparasitismus bei der Kapho- nigbiene Apis mellifera capensis. Die Ver-} bringung von Kaphonigbienen (Apis mellifera capensis Escholtz) aus ihrem natürlichen Verbreitungsgebiet in die nördliche Provinz von Südafrika hat zu einer Parasitierung der dort einheimischen afrikanischen Honigbienen (Apis mellifera scutellata Lepeletier) geführt. Arbeiterinnen der Kaphonigbienen dringen in die Völker von $A$. $m$. scutellata ein und übernehmen die Reproduktion. Als Ergebnis schwinden die Völker dahin und gehen eventuell ein. Hier legen wir Argumente dafür vor, dass neben der Aktivierung der Ovarien und der thelytoken Reproduktion der Kaparbeiterinnen auch die Ernährung der Larven einen wichtigen Faktor bei der Parasitierung der afrikanischen Bienenvölker darstellt. Larven der Kaphonigbienen erhalten mehr und etwas königinnenfuttersaftähnlichere Nahrung sobald sie von Arbeiterinnen anderer Unterarten aufgezogen werden. Dies führt zu Zwischenformen von Arbeiterinnen und Königinnen mit reduzierten Pollenbürsten, vergrößerten Spermatheken und höherer Ovariolenzahl. Die Zwischenformen haben ein höheres Gewicht und entwickeln sich schneller als normale Arbeiterinnen. Dies war bereits bekannt wenn europäische Unterarten als Wirte benutzt wurden (Tab. I, Abb. 1). Wir zeigen 
neue Daten über die Entwicklung von Kaparbeiterinnen erzeugter Brut aus parasitierten Honigbienenvölkern in Pretoria, die wir sowohl in Völkern von A.m. scutellata als auch in Kaphonigbienenvölkern in Stellenbosch aufgezogen haben.

Die in A.m. scutellata Honigbienenvölkern aufgezogene Brut entwickelte sich zu Zwischenformen von Königinnen und Arbeiterinnen, während die in Kaphonigbienenvölkern aufgezogene Brut sich zu normalen Kaparbeiterinnen entwickelte (Abb. 2; Tab. I). Es ist zu erwarten, dass die Königinnen-Arbeiterinnen Zwischenformen im Vergleich zu normalen Kaparbeiterinnen stärker reproduzieren und von den anderen Arbeiterinnen königinnenartiger behandelt werden. Dies wirkt sich wahrscheinlich auf den Parasitismus afrikanischer Honigbienenvölkern durch die Kaphonigbienen in der nördlichen Provinz von Südafrika aus. Darüber hinaus könnten unterschiedliche Ernährungsniveaus mit dem Resultat von weniger distinkten Kastenunterschieden insbesondere während weiselloser Zeiträume für den reproduktiven Erfolg von Honigbienenarbeiterinnen von Bedeutung sein. Hierbei ist die Situation in der Hybridisierungszone von Kaphonigbienen und A.m. scutellata von besonderem Interesse, da eine besonders große Variation zwischen Arbeiterinnen innerhalb der Völker zu erwarten ist.

\section{Apis mellifera capensis / Apis mellifera scutellata / Kaphonigbienen / afrikani- sche Honigbienen; Parasitismus / Lar- venfütterung / Kastendetermination}

\section{REFERENCES}

Allsopp M.H. (1988) Mandibular gland acids and laying workers in African honeybees, in: Needham G.R., Page R.E., Delfinado-Baker M., Bowman C.E. (Eds.), Africanized Honeybees and Bee Mites, J. Wiley \& Sons, New York, pp. 72-79.

Allsopp M.H., Crewe R.M. (1993) The Cape honey bee as a Trojan horse rather than the hordes of Genghis Khan, Am. Bee J. 133, 121-123.
Allsopp M.H., Hepburn H.R. (1997) Swarming, supersedure and the mating system of a natural population of honeybees (Apis mellifera capensis), J. Apic. Res. 36, 41-48.

Anderson R.H. (1963) The laying worker in the Cape honeybee, Apis mellifera capensis, J. Apic. Res. 2, 85-92.

Aron S., Passera L., Keller L. (1999) Evolution of social parasitism in ants: size of sexuals, sex ratio and mechanisms of caste determination, Proc. R. Soc. London B 266, 173-177.

Asencot M., Lensky Y. (1976) The effect of sugars and juvenile hormone on the differentiation of the female honeybee larvae (Apis mellifera L.) to queens, Life Sci. 18, 693-700.

Beekman M., Calis J.N.M., Boot W.J. (2000) Parasitic honeybees get royal treatment, Nature 404, 723.

Beetsma J. (1979) The process of queen-worker differentiation in the honeybee, Bee World 60, 24-39.

Crewe R.M., Velthuis H.H.W. (1980) False queens: a consequence of mandibular gland signals in worker honeybees, Naturwissenschaften 67, 467-469.

Dedej S., Hartfelder K., Aumeijer P., Rosenkranz P., Engels W. (1998) Caste determination is a sequential process: effect of larval age at grafting on ovariole number, hind leg size and chephalic volatiles in the honey bee (Apis mellifera carnica), J. Apic. Res. 37, 183-190.

Hepburn H.R. (1992) Pheromonal and ovarial development covary in Cape worker honeybees, Apis mellifera capensis, Naturwissenschaften 79, 523.

Hepburn H.R., Crewe R.M. (1991) Portrait of the Cape honeybee, Apis mellifera capensis, Apidologie 22, 567-580.

Hepburn H.R., Jacot Guillarmod A. (1991) The Cape honeybee and the fynbos biome, S. Afr. J. Sci. 87, 70-73.

Hepburn H.R., Allsopp M.H. (1994) Reproductive conflict in honeybees: usurpation of Apis mellifera scutellata by Apis mellifera capensis in the Transvaal, S. Afr. J. Sci. 90, 247-249.

Hepburn R., Radloff S.E. (2002) Apis mellifera capensis: an essay on the subspecific classification of honeybees, Apidologie 33, 105-127.

Hepburn H.R., Magnuson P., Herbert L., Whiffler L.A. (1991) The development of laying workers in field colonies of the Cape honey bee, J. Apic. Res. 30, 107-112.

Hepburn H.R., Radloff S.E., Fuchs S. (1998) Population structure and the interface between Apis mellifera capensis and Apis mellifera scutellata, Apidologie 29, 333-346.

Johannesmeier M.F. (1983) Experience with the Cape bee in the Transvaal, S. Afr. Bee J. 55, 130-138.

Kuwabara M. (1947) Über die Regulation im weisellosen Volke der Honigbiene (Apis mellifica), besonders die Bestimmung des neuen Weisels, J. Fac. Sc. Hokkaido Univ. 9, 359-381. 
Lundie A. (1954) Laying worker bees produce worker bees, S. Afr. Bee J. 29, 10-11.

Martin S.J., Beekman M., Wossler T.C., Ratnieks F.L.W. (2002). Parasitic Cape honey bee workers, Apis mellifera capensis, evade policing, Nature 415, 163-165.

Martin S., Wossler T., Kryger P. (2002) Usurpation of African Apis mellifera scutellata colonies by parasitic Apis mellifera capensis workers, Apidologie 33, 215-232.

Moritz R.F.A. (2002) Population dynamics of the Cape bee phenomenon: The impact of parasitic laying worker clones in apiaries and natural populations, Apidologie 33, 233-244.

Moritz R.F.A., Southwick E.E., (1992) Bees as superorganisms, An evolutionary reality, Springer-Verlag, Berlin, 395 p.

Moritz R.F.A., Kryger P., Allsopp M.H. (1996) Competition for royalty in bees, Nature 384,31 .

Neumann P., Hepburn R. (2002) Behavioural basis for social parasitism of Cape honeybees (Apis mellifera capensis), Apidologie 33, 165-192.

Nonacs P., Tobin J.E. (1992) Selfish larvae: development and the evolution of parasitic behavior in the Hymenoptera, Evolution 46, 1605-1620.

Onions G.W. (1912) South African 'fertile worker bees', S. Afr. Agric. J. 1, 720-728.

Onions G.W. (1914) South African 'fertile worker bees', Agric. J. Un. S. Afr. 7, 44-46.

Radloff S.E., Hepburn R., Neumann P., Moritz R.F.A., Kryger P. (2002) A method for estimating variation in the phenotypic expression of morphological characters by thelytokous parthenogenesis in Apis mellifera capensis, Apidologie 33, 129-137.

Ratnieks F.L.W. (1993) Egg-laying, egg-removal, and ovary development by workers in queenright honey bee colonies, Behav. Ecol. Sociobiol. 32, 191-198.

Ratnieks F.L.W. (1995) Evidence for a queen-produced egg-marking pheromone and its use in worker policing in the honeybee, J. Apic. Res. 34, 31-37.

Ratnieks F.L.W. (2001) Heirs and spares: caste conflict and excess queen production in Melipona bees, Behav. Ecol. Sociobiol. 50, 467-473.
Ratnieks F.L.W., Visscher P.K. (1989) Worker policing in the honeybee, Nature 342, 796-797.

Reece S.L. (2002) A scientific note on the ovarial and pheromonal development of drifted and nondrifted Cape honeybee workers (Apis mellifera capensis), Apidologie 33, 213-214.

Shuel R.W., Dixon S.E. (1959) Studies in the mode of action of royal jelly in honeybee development. II. Respiration of newly emerged larvae on various substrates, Can. J. Zool. 37, 803-813.

Simon U.E., Moritz R.F.A., Crewe R.M. (2001) The ontogenetic pattern of mandibular gland components in queenless worker bees (Apis mellifera capensis Esch.), J. Insect Physiol. 47, 735-738.

Velthuis H.H.W. (1970) Ovarian development in Apis mellifera worker bees, Entomol. Exp. Appl. 13, 377-394.

Velthuis H.H.W., Ruttner F., Crewe R.M. (1990) Differentiation in reproductive physiology and behaviour during the development of laying worker honeybees, in: Engels W. (Ed.), Social Insects, Springer Verlag, Berlin, pp. 231-243.

Wirtz P., Beetsma J. (1972) Induction of caste differentiation in the honey bee (Apis mellifera) by juvenile hormone, Entomol. Exp. Appl. 15, 517-520.

Wossler T.C. (2002) Pheromone mimicry by Apis mellifera capensis social parasites leads to reproductive anarchy in host Apis mellifera scutellata colonies, Apidologie 33, 139-163.

Wossler T.C., Crewe R.M. (1999) Mass spectral identification of the tergal gland secretions of female castes of two African honey bee races (Apis mellifera), J. Apic. Res. 38, 137-148.

Wossler T.C., Veale R.B., Crewe R.M. (2000) How queen-like are the tergal glands in workers of Apis mellifera capensis and Apis mellifera scutellata?, Apidologie 31, 55-66.

Wossler T.C., Martin S., Beekman M., Ratnieks F. (2001) Delinquent honeybee workers, Proc. 13th Entomological Congress, The Entomological Society of Southern Africa, Pietermaritzburg, p. 77.

Woyke J. (1979) New investigations on Apis mellifera capensis, Apiacta 14, 173.

Woyke J. (1999) Increased food supply to all larvae after dequeening honey bee colonies, J. Apic. Res. $38,117-123$. 